\title{
A Practical Journey in Implementing a Shari'ah Compliant Hospital: An Nur Specialist Hospital's Experience
}

\author{
Shaharom Md Shariff ${ }^{1}$, Shahimi Mohtar ${ }^{1}$, Roslan Jamaludin ${ }^{1}$ \\ ${ }^{1}$ School of Technology Management and Logistics, Universiti Utara Malaysia
}

\begin{abstract}
Research on Islamic products and services has been receiving great attention over the past years. This has attributed to the increasing awareness among Muslims to consume Halal products or served with Shari'ah compliant services. In responding to this development, An Nur Specialist Hospital has initiated to be the first private Shari'ah Compliant Hospital (SCH), through the award of the MS 1900:2014 in April 2015. MS1900:2014 provides guidelines for an organization to be accredited as a Shari'ah compliant organization. The Ministry of Health, Malaysia has introduced 'îbädah friendly hospital' in 2010. However, there is lack of research on the characteristics and implementation of $\mathrm{SCH}$ in the healthcare industry. Therefore, the purpose of this paper is to understand the implementation of $\mathrm{SCH}$ at An Nur Specialist Hospital. A qualitative case study is utilised to investigate the issues and implementation of $\mathrm{SCH}$. The case study uses in-depth, open-ended interview with the hospital senior management. The interview was recorded, transcribed, and evaluated based on thematic analysis to understand the practice. The study found major outcomes in implementing $\mathrm{SCH}$, such as the important role of the Shari'ah Advisory Council in ensuring all the Standard Operating Procedures are in line with Shari'ah principles, continuous staff development programs in providing the Shari'ah understanding and latest fatwā on Fiqh Medic. The other outcome is the positive response from patients who have been frequently visiting the hospital due to the status of An Nur as a SCH.
\end{abstract}

KEYWORDS: Shari'ah, Shari'ah Compliant Hospital, İbadah Friendly Hospital, Maqāşid Shari'ah, Islamic products and services, Healthcare

\section{INTRODUCTION}

It is every Muslims' obligation as Allah's vicegerents to uphold the Shari'ah principles in all aspects of their lives. Allah ordained in the Qur'an "I have only created Jinns and men, that they may serve Me". ${ }^{1}$

The purpose of creation is to worship Him alone and hence every Muslim's life activity is for obedience, submission and devotion ('ibadah). Thus the performance of 'îbadah in all aspects of one's life can only be fulfilled is through the implementation of the Shari'ah . According to a famous Muslim jurist, Ibn al-Qayyim (d. 1347 AD). ${ }^{2}$ Shari'ah is also aimed at governing individual and societal affairs in life so as to uphold justice, mercy, wisdom and the common good in human dealings. If one violates the four principles stated above is not considered Shari'ah. ${ }^{3}$ Thus Shari'ah is the Islamic law that governs the Muslims' life in all aspects as 'ībadah (worship), muロĀmalah (dealings with a fellow

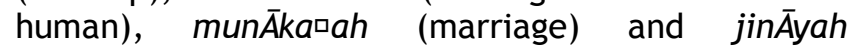
(criminality). Shari'ah is rules and regulations that determine the lawful and unlawful dealings in the Muslims' life. The total intent is to provide justice in all dealings. Many Muslims have now made aware and realised the importance of adhering to the Shari'ah in all aspects of life.

Corresponding author:

Shaharom Md Shariff

Universiti Utara Malaysia

Email : shaharomshariff@gmail.com
New products or services based on Shari'ah has been introduced into the market due to the awareness amongst Muslim. The Islamic Banking and Finance is a good success story which has made inroads into the Financial and Banking Sector. Over the last few decades when these products were virtually unknown in the market place, Malaysia has been a pioneer in introducing these Shari'ah compliant products. ${ }^{4}$ The trend to introduce more Islamic based products becomes more pronounced when there are overwhelming responses not only from Muslims but also from non-Muslims.

Malaysia, a multiracial country with a population of 31.5 million has $68.5 \%$ of its population Muslim and Islam is the largest practised religion. ${ }^{5}$ Being a Muslim country, Malaysia has been innovative and a pioneer in many Islamic products. Many of these products are first to be introduced in the Muslim world. In the Halal products, Malaysia introduced standard MS 1500:2004 which forms the guidelines in Halal Products and Services. ${ }^{6}$ In the Finance and Banking industry, Malaysia introduced the Islamic Banking and Finance Products since 1983 with the Islamic Banking Act 1983 and Takaful Act 1984. ${ }^{7}$

Since its inception, the phenomenal development with a double-digit annual growth has allowed profit opportunities for the financial institution. Islamic banking is now a promising business in the financial services industry. It has experienced a tremendous 
growth just after three decades of its inception. There are now over 300 Islamic financial institutions worldwide across 75 countries. ${ }^{8}$ According to the Asian Banker Research Group, The World's 100 largest Islamic banks have set an annual asset growth rate of $26.7 \%$ and the global Islamic Finance industry is experiencing an average growth of 15$20 \%$ annually. The Islamic banking assets are expected to reach USD 1 trillion by 2010 as stated by a study conducted by McKinsey \&Company in 2007..$^{8}$ Since Muslims are obliged to observe the Shari'ah in all aspects of their lives, the introduction of a Shari'ah Compliant Hospital $(\mathrm{SCH})$ will add as another innovative product.

Hospitals are institutions where the healthcare services are being rendered in the form of inpatients, outpatients, and emergency services. For a $\mathrm{SCH}$, the healthcare services are rendered in accordance with the Shari'ah principles or Islamic teachings. ${ }^{9}$ Unlike other Islamic products, a $\mathrm{SCH}$ is not product based per say, like products from an Islamic bank or financial center, rather $\mathrm{SCH}$ is an organisation based which has a scope of work, standard operating procedures,SOPs and staffing requirements. All these SOPs are to comply with Shari'ah principles in totality. ${ }^{9}$ A product per say should not unilaterally claim to be Shari'ah compliance, rather the whole institution needs to be certified by an independent body which is authorised to carry out the accreditation process in accordance to MS1900:2014. This is to ensure that the organisation is following procedures as per Shari'ah requirements.

In Malaysia, SIRIM Berhad, formerly known as Standard and Industrials Research Institute of Malaysia, is a company appointed by Department of Standards Malaysia as the government agency to develop, accredit and certify standards. It is the International Organisation for Standardisation (ISO) local representative as the certification agency. SIRIM has developed a general Shari'ah based Quality Management System (MS 1900:2014) based on ISO 9001:2008. ${ }^{10}$ The MS 1900:2014 provides general guidelines for any organisation which desires to implement a Shari'ah based quality management system. The framework is as per figure 1.

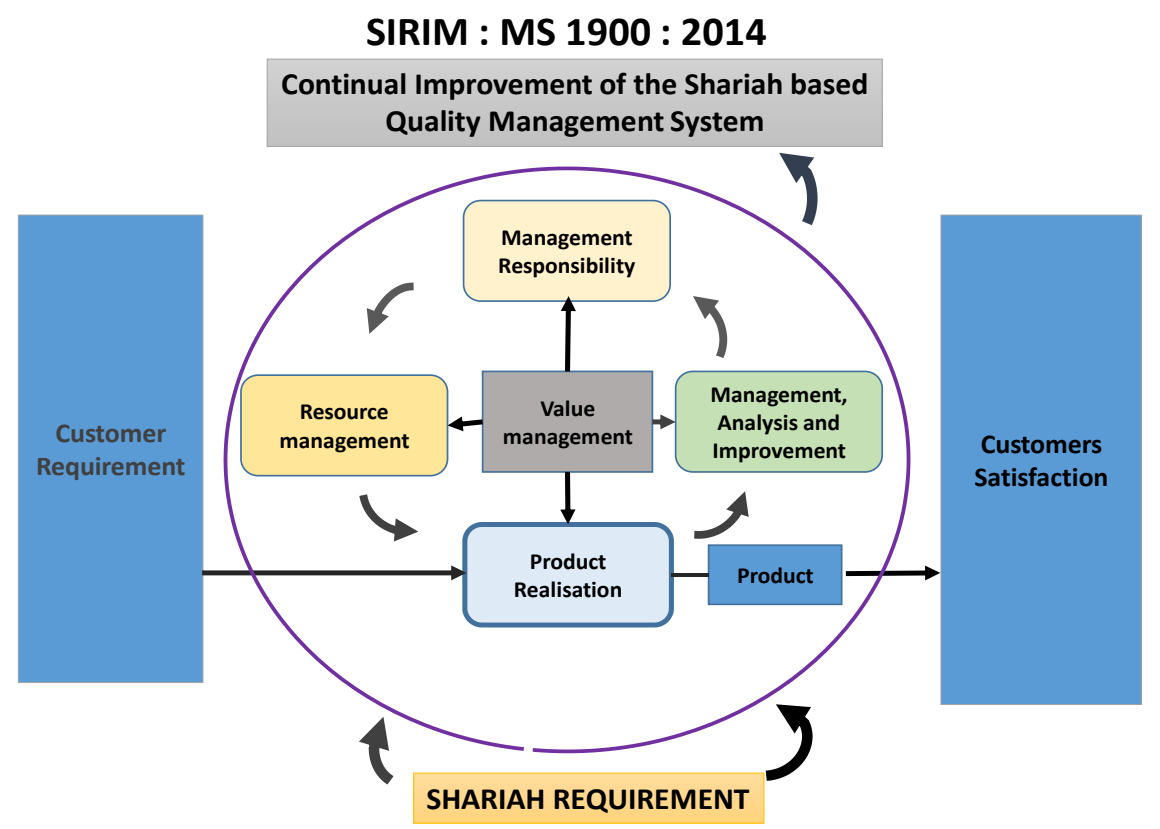

Figure 1 : Model of a Shari'ah based Quality Management System (Source: SIRIM MS 1900:2014. )

This generic framework of Shari'ah based quality standard can be guided to any industry. For the specific industry as in healthcare, a conceptual framework will need to be developed that complies with Shari'ah Compliant Medical Practice Quality System together with the hospital support services. The framework will require to be translated into a practical framework that is appropriate in the hospital environment. For $\mathrm{SCH}$, all the Standard Operating Procedures (SOP) of the hospital management will require to conform to MS 1900:2014. SCH does not only cater for the physical needs of patients, it also allows and facilitates for the religious and spiritual needs of patients. It is well known fact that the role of spirituality and religiosity has widened and is now more acknowledged not only in Oriental culture but also in the Western world. ${ }^{11}$

As mentioned earlier, for a Muslim all his daily activities are preferred to be in line to Islamic principles because if these activities are in accordance with Shari'ah or Islamic principles then they are considered as 'íbadah. Hence a SCH provides an avenue for those who always desire to 
achieve Islamic fulfilments and obligation in their personal and professional lives devoid of dichotomy and dualism.

It can be clearly stated that the development of a $\mathrm{SCH}$ would require the establishment of the necessary conceptual framework and documents that can comply with the MS 1900:2014 Shari'ah Based Quality Management System Requirement with Guidance for the purpose of providing SOP to the intending hospital and later implementing those SOP as per the guidelines. The documents will become a guideline for other hospitals. The conceptual framework developed at An Nur Specialist Hospital has been practically tested and had received the certification of MS 1900:2014. ${ }^{9}$

There is also another initiative in this region that also specify the conditions for a $\mathrm{SCH}$. In Indonesia through the consortium of Islamic Healthcare Consultative Council of Indonesia (Majelis Syuro Upaya Kesehatan Islam Indonesia, MUKISI), MUKISI has developed the specification of $\mathrm{SCH}$, based on the Hospital Accreditation Committee (Komite Akreditasi Rumah Sakit, KARS ) system. ${ }^{12}$

The study will focus on how An Nur Specialist Hospital has developed from the conceptual framework into practical documents as SOPs and tested for the practical purpose to the extent of obtaining accreditation as $\mathrm{SCH}$ based on MS1900:2014.

\section{LITERATURE REVIEW}

There are very limited literature written specifically on $\mathrm{SCH}$. The nearest topic is the paper presented as Conference Proceeding. ${ }^{13}$ In that particular study, the hospitals selected were based on İbadah friendly rather than Shari'ah compliance. A qualitative case study was carried out on two hospitals - Al Islam Specialist Hospital in Kuala Lumpur and USM Hospital in Kubang Kerian Kelantan. The focus was on how these hospitals have attracted Medical Tourism by complying with Shari'ah practices. Another quantitative study conducted on medical tourists towards Muslim friendly medical tourism which highlighted the potential demand for Shari'ah compliant medical tourism. The study was based on two government and two private hospitals. But the hospitals were still based on Shari'ah practices, not $\mathrm{SCH} .{ }^{14}$

The other related study in services industry is Shari'ah compliant hotel in Malaysia . The concept of Shari'ah compliant hotel is still new. ${ }^{15}$ It covers a wide range of features and characteristics of the Shari'ah compliant hotels found in Malaysia. Although the study discovered that the Shari'ah compliant hotel did cover the whole gamut of services offered by the hotel, however, the study suggested that as a Shari'ah compliant hotel, the Shari'ah principles should cover the entire operation of the hotel organisation. ${ }^{16}$
In the study by A Jurattanasan, ${ }^{17}$ he outlined the features of a Shari'ah compliant Hotel practiced in Muslim countries. The features include 1. No alcohol, 2. Halal food only, 3. Conservative television service, 4. The majority of staff of Muslim faith, 5. Quran \& Prayer mats available in each room, 6. Separate recreational facilities for men \& women, 7. Makers in the rooms indicating the direction of Mecca, 8. No entertainment such as night club, 9. Bed \& Toilet should not be placed to face the direction of Mecca, 10. Art in the hotel should not depict the human form,11. Bidets in the bathrooms, 12. Appropriate entertainment, 13. Hotel financed through Islamic Financial arrangement and 14. Hotel should follow the Zakat principles. The same features related to rooms can be applied for the inpatient wards of $\mathrm{SCH}$. Though these features are common to many Shari'ah compliant hotel, there are no formalised criteria to categorise that a hotel is a Shari'ah compliant hotel. ${ }^{18}$

\section{Maqāşsid Shari'ah and Healthcare}

The word MaqĀşid (plural of maqșad) means goals or purposes. However, MaqĀșid Shari'ah in this instance refers to the goals or purposes of Islamic law. ${ }^{19}$ Maqāssid of the Islamic law highlights rationales, purposes and the common good in the Islamic rulings and stresses their importance while basing itself on the Islamic scripts and observing the Islamic faith. ${ }^{20}$ Many Muslim scholars came to the consensus that the ultimate objective of MaqĀsid Shari'ah is to serve the benefits (mașlaロah) for humankind and to protect them from harm (mafsada). ${ }^{19}$ The traditional classification has been to divide the maqĀssid according to 3 "levels of necessity". - absolute necessities (arūriyy $\bar{A} t$ ),

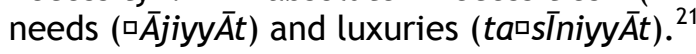

The necessities are then further classified into 5 categories namely the importance of preserving the well-being of the people through the safeguarding of their faith (dIn), their lives (nafs), their intellect ('aql), their posterity (nasl), and their wealth $(m \bar{a} l) .{ }^{3}$ When these are fulfilled adequately, it has served the public interest and is therefore desirable. However, any acts or works which are not in accordance with the above five points is against the interest of the public and therefore should not be pursued.

Ibn Ashur (2006) $)^{22}$ explains that the maqĀșid, besides promoting the well-being and virtue of man, it also ensures that the social order of the community is preserved in a healthy progress. This virtue will only be fulfilled through intelligent thinking and also by carrying out good deeds, as well all the gifts that God has bestowed on him are being utilised in a righteous manner that brings benefit to the society as a whole.

Ahmad al Raysuni ${ }^{23}$ in supporting the idea for an all encompassing guide to a well-ordered and fulfilling human civilization, pointed out that the maqAșid is aimed at the preservation of an ordered and peaceful society. The people that are placed on 
IMJM Volume 17 Special Issue No 2

this earth will act as its responsible caretakers and God had placed them as His vicegerents on this earth. As such, all the resources at his disposal has to be utilised wisely and therefore they must live justly and promote moral proprietary and integrity for the benefit of all in thought and action.

Basically MaqĀşid Shari'ah has four main characteristics. MaqĀșid Shari'ah firstly, which forms the foundation of legislation aims for the benefit of all human beings and preserving them from harm. Secondly, as their objectives in trying to serve the needs and interests of all mankind they are universal in character. That includes all and require their total obedience and acceptance. Next since it is encompassing all human acts irrespective of whether they relate to the responsibilities of God ('îbadah) or to the responsibilities of other human beings (mu'āmalah) they are are inclusive or absolute in nature. Finally, MaqĀșid Shari'ah have been taken from many different sources, and not just from one single text or item of evidence Maqāșid Shari'ah is definitive. ${ }^{24}$

Maqāșid Shari'ah as required by Islam should be observed in its entirety and not partially. This is because Islam encompasses all patterns of life and its objective does not just address both the personal and public sides of life, but it also covers the life in the Hereafter. Public interest or Mașlarah is at the core of MaqĀșid Shari'ah itself, and as such, the general objective of Shari'ah lays in ensuring the order of society is being preserved and its steady and healthy progress are also being observed. ${ }^{3}$

In this context, the healthcare has a role in enhancing and safeguarding of life and health. The Quran, in Surah Al Ma'idah ayat 32, says “...if anyone saves a life, it would be as if he saved the life of all mankind". ${ }^{25}$ This further elaborates that healthcare practitioners would take greater care to ensure proper steps are taken to ensure the sanctity of human being. The value of human life is expressed in the following hadith: It was narrated that 'Abdullah bin 'Amr said:

"I saw the Messenger of Allah (䠣) circumambulating the Ka'bah and saying: 'How good you are and how good your fragrance; how great you are and how great your sanctity. By the One in Whose Hand is the soul of Muhammad, the sanctity of the believer is greater before Allah than your sanctity, his blood, and his wealth, and to think anything but good of him." (Ibn Majah 3931). These indicate the certainty that the enhancement and preservation of life and health are definitive objectives of Shari'ah.

The other pertinent issue in today's environment is that, Islam is perceived as incapable of responding to all human needs based on the principles of justice, peace, freedom and equity. Ibn Ashur ${ }^{20}$ defines the MaqĀssid Shari'ah is to preserve the social order of the community. It also promotes the community's progress ordaining the well-being and virtue of human being. The Shari'ah is also aimed at propagating, protecting and preserving the essentials of our existence on earth. These essentials have been priorities based on decreasing importance as al-Din religion), nafs (life), aql (intellect), nasl (progeny) and $m \bar{A} l$ (property ) as outlined in aims of the Shari'ah (Maqāșid alShari'ah). ${ }^{26}$

The rationale of MaqĀşid Shari'ah is to bring about individual benefits and community at large. The Shari'ah is designed to protect these benefits and provide facilities for the perfection of human life on the earth. The Shari'ah seeks to establish justice, eliminate animosity and alleviate friendship, love and kindness amongst human being.

Figh ībadah relates to how patients are being reminded in term of continuation of their practices in observing Islamic obligations while undergoing medical treatment. The related items are mainly concerning daily prayers (salat), fasting and also issues pertaining to cleanliness and physical purity (țahārah). Fiqh Mu'āmalat meanwhile relates to business and financial transactions which are free from forbidden $(a r \bar{A} m)$ elements including interest (rība), uncertainty (gharar) and gambling (maisir). ${ }^{27}$ This also covers contracts and financing facilities transacted between the hospital and any third party dealings.

\section{SIRIM's Functions and MS1900:2014}

The Department of Standards Malaysia (Standard Malaysia), under the Ministry of Science, Technology and Innovation is the national standards and accreditation body in Malaysia. Standard Malaysia was set up on 28 August 1996 following the restructuring of the Malaysian standardization system in accordance with the Standards of Malaysia Act 1996 (Act 549). It is also responsible for accreditation since it assumed responsibility for all activities previously undertaken by the Malaysian Accreditation Council.

SIRIM Berhad, is the sole national standards development agency and was appointed by Standard Malaysia. SIRIM Berhad, a company wholly owned by the Malaysian Government, was established on 1 September 1996 as a successor company to the Standards and Industrial Research Institute of Malaysia (SIRIM) upon the enactment of the Standards of Malaysia Act in $1996 .{ }^{28}$ In term of standard, SIRIM QAS International Sdn. Bhd. (SQI) is Malaysia's leading certification, inspection and testing body.$^{29}$ After over three decades of providing certification, inspection and testing services under SIRIM Berhad, SQI was established as a whollyowned subsidiary of the SIRIM Group in March 1997. Today, local and international customers from a wide cross-section of the economy have made SQI the preferred choice for their certification, inspection and testing needs.

SQI is an accredited certification, inspection and testing services provider under numerous bodies, including the National Accreditation Body, Standard Malaysia and the United Kingdom Accreditation Service (UKAS) among others. As the national 
standards development agency, their extensive expertise in standards and certification helps local companies' products meet the requirements of international markets. ${ }^{29}$

The MS 1900 standard specifies the requirements for a Shari'ah-compliant Quality Management System. It ensures that an organisation is managed in accordance with universally accepted values such as justice, honesty, truthfulness, sincerity, timeliness and discipline. ${ }^{30}$ It also ensures that the halal and non-halal aspects of all processes necessary for the delivery of products and services are effectively identified, communicated and implemented. ${ }^{30}$

The MS 1900 features a Shari'ah component by taking into consideration the element of AqTdah, Akhläk and Fiqh. In the case of Fiqh as an example, the MS 1900 will observe how it is being incorporated into the corporate values of the company. ${ }^{30}$ There is also Shari'ah Advisory Council whose function is to ensure that the audit performed by SQI is being carried out in a professional manner and the Shari'ah components are being properly evaluated. In the paper by NZ Md Salleh (2014) it was strongly suggested that MS 1900:2005 be used as a tool in the practice of Shari'ah Compliant Hotel. ${ }^{16}$

\section{Shari'ah Compliant Institutions}

According to SIRIM there are already 31 Shari'ah Complaint Institutions certified under MS 1900:2014. The Standard was first introduced in 2005 with a targeted 10 pilot companies to undertake to be certified. However there were 5 companies that took up for the pilot and finally, the first group of 4 companies were certified in 2008.

There are 11 sectors of industry being certified with the biggest number in Islamic Institution like Jabatan Pusat Zakat. The sectors covered are Government, Consultancy Services, Education, Fertiliser, Financial, Healthcare, Hotel, Takaful, Islamic Institution, Logistics, and Pharmaceutical.

The latest addition to the list were 3 companies in 2015. Efforts are being promoted to create awareness of this Standard to companies.

Challenges faced during the initial years when the Standard was first introduced by MS Certification Department, SIRIM QAS International Sdn Bhd., among others:

1. Awareness creation to potential companies and government agencies.

During the initial stage, there was lack of expertise to carry out marketing activities.

SIRIM invited companies and government agencies to make them understand the Standards.

2. Consultancy companies to conduct the training for the document preparation and implementation.

There was no company to conduct the training. SIRIM training division created the Shari'ah based training module for potential companies.

3. Expertise in Shari'ah to carry out the auditing SIRIM initially engaged graduates in Shari'ah which was difficult to get by.- Presently SIRIM has trained 20 of SIRIM auditors to undergo certificate in Shari'ah conducted by University Science Islam Malaysia, USIM. 16 made the mark and this will provide SIRIM enough auditors to carry out the Shari'ah based auditing. The Shari'ah based provide opportunities for Shari'ah graduates to be engaged in new field instead of financial sectors and Islamic institution.

\section{The SCH Concept}

In 2010, the Ministry of Health, Malaysia introduced ibadah friendly hospital" to several government hospitals namely HUSM Kubang Kerian, Kelantan, Hospital Pulau Pinang, Hospital Pakar Sultanah Fatimah Muar Johor, Hospital Selayang Selangor, and Hospital Langkawi. In the private sector, the same concept of îbadah friendly hospital was introduced at Hospital Pakar Perubatan Al-Islam Kampung Baru, Kuala Lumpur. Ibadah friendly hospital is a concept used in hospital management to achieve the values of excellence and pride to employees for the well-being of its customers through the adoption and appreciation of worship during and after treatment. Ibadah friendly hospital aims to create awareness through education of patients and families to be more closer to God. ${ }^{13}$

The hospital management is strongly committed to create awareness and actions to facilitate their patients to continuously maintain their obedience to Allah. As a hospital that upholds Islamic values, management provides religious officials to assist and provide guidance to patients. They will visit the patients in daily routine to help patients worship and provide training and guidance to employees about Islam for them to be able to assist the patients. In addition to basic facilities to perform the ritual namely direction of Qiblah, veil, prayer mats, water spray and dust for tayĀmum (dry ablution) are made available. The patients will be assisted and guided by an ustaz (male religious teacher) for male patients and an ustazah (female religious teacher) for female patients to perform worship when in pain, which is consistent with the of Hospital Mesra ĩbadah (worship friendly). ${ }^{13}$

As noted by Kasule, ${ }^{31}$ seven criteria for $\mathrm{SCH}$ includes: 1. Architectural design 2. Having strong financial status 3 . High technology and high quality 4. Services that open to all regardless of religion or creed 5. Provision of wholesome modern up to date scientific med cal care 6 . Holistic patient care in respect to physical, mental, emotional, spiritual and social needs 7 . Services and procedures that do not contradict to the principles of Shari'ah. ${ }^{32}$

According to Kamaruzzaman ${ }^{33}$ the broad guidelines for $\mathrm{SCH}$ will include the following:1. Quality hospital management process. 2. Financial management with Shari'ah principles. 3. Adequate facilities for a 
quality patient care. 4. Adequate facilities and policies for patients and staffs to perform वIbadah (compulsory Islamic ritual) and other religious obligations including dress code covering the awrah.

5. All products (foods and medicines) and procedures used are halal. 6. All procedures especially nursing procedures (SOP) must incorporate Shari'ah needs. 7. Having guidelines to handle Muslim and other patients. 8. Having trained staffs to advise Muslim patients regarding albadah and rukssah. 9. Having a panel of expert to advice the hospital management on Shari'ah compliance.
10. Having a regular assessment including clients' ${ }^{32}$

\section{RESEARCH METHODOLOGY}

The study adopts the qualitative case study approach at An Nur Specialist Hospital. The focus is on developing a theoretical framework of a $\mathrm{SCH}$ and implementing the framework. The whole activities can be shown as in Table 1. The study also conducted an unstructured face to face interview with the management of the hospital. The feedback of the interview is extracted in the next section.

Table 1. The Activities Chart towards MS 1900:2014

\begin{tabular}{|c|c|c|c|c|c|c|c|}
\hline Activities & Date & $\begin{array}{l}\text { Jul }- \text { Dec } \\
2012\end{array}$ & $\begin{array}{l}\text { Jan -Jun } \\
2013^{-J}\end{array}$ & $\begin{array}{l}\text { Jul - Dec } \\
2013\end{array}$ & $\begin{array}{l}\text { Jan } \\
2014^{-}\end{array}$ & Jun & $\begin{array}{l}\text { Jul }- \text { Dec } \\
2014\end{array}$ \\
\hline $\begin{array}{l}\text { Appointment Of Quality Unit And } \\
\text { Management Representative }\end{array}$ & $\begin{array}{l}1^{\text {st }} \\
\text { July'12 }\end{array}$ & a & & & & & \\
\hline Competency Training for Quality Unit & Jul',12- & & & & & & \\
\hline Training of ISO $9001: 2008$ & Oct'12 & & & & & & \\
\hline Appointment Of Internal Auditor & $2^{\text {nd }}$ Sept & $\mathbf{m}$ & & & & & \\
\hline $\begin{array}{l}\text { Additional Training QMS -MS } \\
\text { 1900:2005 }\end{array}$ & Oct '13 & & & $\mathbf{m}$ & & & \\
\hline $\begin{array}{l}\text { Appointment of Shari'ah Advisory } \\
\text { Council }\end{array}$ & $1^{\text {st }}$ Dec & & & $\mathbf{m}$ & & & \\
\hline $\begin{array}{l}\text { Planning \& Execution of Audit QMS } \\
\text { effective } 2^{\text {nd }} \text { Jan } 2014\end{array}$ & Jan-Jul & & & - & & & \\
\hline Formal Internal Audit & Apr- Jul & & & & & & \\
\hline SIRIM Audit ( $1^{\text {st }}$ Stage $)$ & $26^{\text {th }}-$ & & & & & $\mathbf{\square}$ & $\mathbf{m}$ \\
\hline SIRIM Audit ( $2^{\text {nd }}$ Stage $)$ & $28^{\text {th }}$ & & & & & & $\boldsymbol{\square}$ \\
\hline Certification of ISO $9001: 2008$ & $\begin{array}{l}10^{\text {th }} \\
\text { April } \\
2015\end{array}$ & & & & & & \\
\hline Certification of MS 1900:2014 & $\begin{array}{l}28^{\text {th }} \\
\text { May } \\
2015\end{array}$ & & & & & & \\
\hline
\end{tabular}

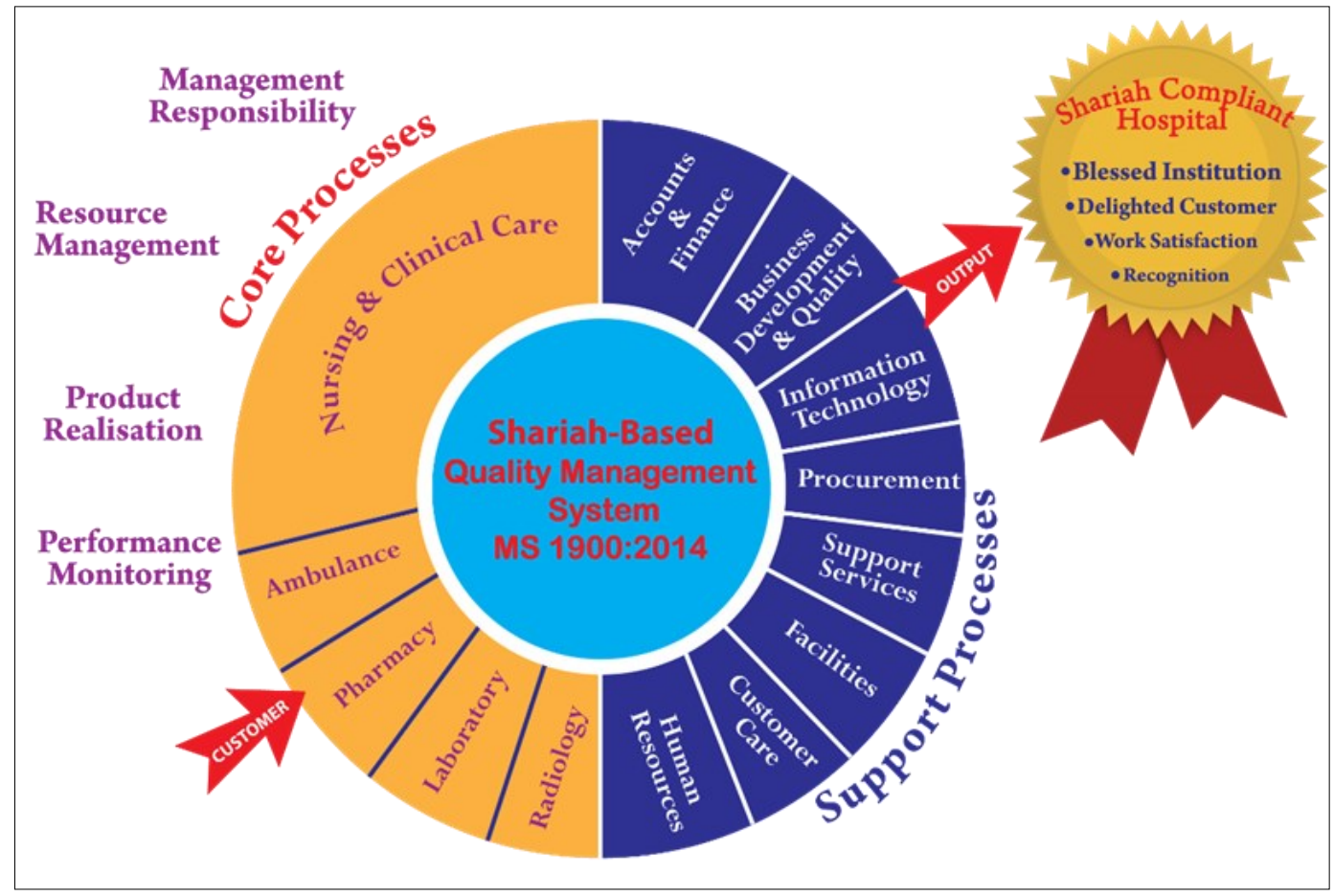

Figure 2. Conceptual framework for Shari'ah Compliant Hospital, SCH: (courtesy of An Nur Specialist Hospital) 
The qualitative approach is also to uncover the understanding from experts who have implemented and being accredited with MS 1900:2014. The qualitative approach is most appropriate since there are still lack of quantitative data on $\mathrm{SCH}$ at the moment.

Qualitative case study methodology provides tools to study complex phenomena within their contexts. When applied correctly, it becomes a valuable method for healthcare researcher to develop theory, evaluate programs, and develop interventions. ${ }^{34}$ According to Yin, case studies can be used to explain, describe or explore events or phenomena in the everyday contexts in which they occur. ${ }^{35}$

The conceptual framework developed as per figure 2.

From the above framework the detailed SOPs were then developed. Initially the framework was meant for ISO 9001:2008. However when SIRIM informed that there is MS 1900:2005 for Shari'ah based Quality Management System, then An Nur management decided to submit for MS 1900:2005.

In incorporating the SOPs with what is termed as the Shari'ah Critical Control Points (SCCP), the SCCPs has to be guided by a Shari'ah Advisory Council (SAC). The SAC is formed as part of the Organisational Structure to be referred whenever issues related to Shari'ah arises. All the SCCP discussions require the SAC endorsement in all relevant matters for the purpose of implementation. The SAC consists of members who are Islamic jurisprudence experts will collectively provide advices on Shari'ah . The major SCCP items cover aspects of Fiqh íbadah.At times items related to Mu'âmalat are also being discussed.

Besides the presence of a SAC in its organisation structure, the hospital will also engage positions for Shari'ah Compliant Officers (SCO) whose function will be attending day to day operational issues of the hospital. The SCO will also report any abnormalities and register them for the next Shari'ah committee meeting.

The basic characteristic components that reflect a $\mathrm{SCH}$ are as follows: 1.Understanding the basic principles of Shari'ah, 2.Understanding the principles of $a l \bar{A} l$ and $a r \bar{A} m, 3$. Understanding the principles of ĩbadah and Mu'àmalat 4.Implementing the Concept of Quality in Islam, 5.Establishing 'Islamic Core Values' within the organisation which runs the hospital

\section{Implementation Strategies}

The strategies allow for 3 stages approach whereby Stage 1 is the documentation preparation. Stage 2 is the human capital preparation where the training of all the staff was carried out. In Stage 3 it is where the Accreditation by SIRIM took place. At this stage any Non Compliance will also be rectified within the specified timeframe ordained by SIRIM before SIRIM can award the certificate.

Stage 1 - Preparation of Documentation

The documentation for all the SOPs are shown in Figures 3 and 4 . The common documents are those related to Work Ethics, Medical Practitioners Ethics, Medical Fiqh and Patients Care Ethics. For the Core Processes, the Clinical related Shari'ah issues are in the Nursing department, Pharmacy and those shown in Figure 3. For the Support Services related to Shari'ah issues are Account \& Finance, Human resources and others as in Figure 4. Only those related to Shari'ah issues are being registered in the SCCPs. The preparation of these documents are critical before any training can be carried out. During this stage too identification of the Internal Auditors who will be the core team to be trained to handle internal auditing functions. They will ensure the readiness of the organisation before examination by the external auditors in this case SIRIM.

There is also the îbadah booklet and kit for inpatient which relate to prayer and fasting. This booklet provides guidelines for the patients to continue their devotion even when they are sick. The nurses are trained to assist if they are in doubt. Both figures indicated are those SOPs which have Shari'ah issues discussed in the SAC. For those without Shari'ah issues, normal SOPs prevail.

\section{Stage 2 - Development of Human Resources and}

Environment

At this stage, the training of all the staff in the organisation is being carried out. The training includes the basic vision, mission, core values and also the common items such as work ethics, medical figh as shown in Figure 3. The Core Processes of SCCPs for their particular department are also covered. Similarly for Support Services as in Figure 4 , the related SCCPs issues are also being discussed and to be understood.

Besides the trainings, the other activities include the weekly tazkīrah program, usrāh and also the monthly Majlis Ilmu as a supportive program. All these programs are part of the processes in transforming the organisation to ensure the staff are fully equipped to be engaged as $\mathrm{SCH}$. The core values were also explained and discussed during weekly tazkīrah.

\section{Stage 3 - Accreditation}

The internal audits are responsible to ensure the readiness of the organisation to call for external audit. There were two cycles of auditing carried out before the external audit was called. The first internal audit were carried out from $1^{\text {st }}$ to $15^{\text {th }}$ April 2014. Seventeen non compliance items and eight observations items were identified. The various departments were given two months to rectify before the next internal audit were carried out on $7^{\text {th }}-11^{\text {th }}$ July 2014 . Twenty observations items were pointed out. After the second cycle, the organisation submitted to SIRIM to carry out the $1^{\text {st }}$ 
IMJM Volume 17 Special Issue No 2

stage audit involving documentation. On $26^{\text {th }}-27^{\text {th }}$ October 2014 SIRIM audit members came and identified eight items under QMS mandatory documentation needed improvement. The corrections were submitted on $18^{\text {th }}$ November and the $2^{\text {nd }}$ stage audit was expedited on $27^{\text {th }}-28^{\text {th }}$ November 2014.

\section{FINDINGS AND DISCUSSION}

An Nur Specialist Hospital situated in Bandar Baru Bangi Malaysia is the first private hospital in Malaysia to be awarded the MS 1900:2014 on 28th May 2015. Its practical journey in implementing Shari'ah compliance started in 2012. The initial preparation towards $\mathrm{SCH}$ began with staff training in basic understanding of Maqāşid Shari'ah and the requirements to comply with MS 1900:2005 which was later an upgraded to the new version MS 1900:2014. In October 2014, the documentation audit by SIRIM was carried out and later the ground audit was carried out from 27th to 28th November 2014. The audit resulted in nine areas of Non Compliance (NC) and 27 minors areas for improvement identified.

The necessary corrections and amendments were corrected within a month after the ground audit. An Nur's achievement has spurred similar interest from neighbouring countries including Indonesia and Brunei. It is hoped that the model created in An Nur will serve as reference for similar initiatives not only in the South East Asian Region but throughout the Muslim world.

An interview was conducted with the Chief Operating Officer of An Nur Specialist Hospital on $28^{\text {th }}$ March 2016. The areas of coverage include,

1. Hospital operation before and after being $\mathrm{SCH}$.

2. The continuous staff development program to ensure the transformation of core values are being assimilated into work culture.

3. The facilities and program for patients after $\mathrm{SCH}$.

4. The supporting facilities required to implement $\mathrm{SCH}$.

The outcome of the interview is mentioned below; The significant changes before and after the implementation of $\mathrm{SCH}$, are the establishment of Shari'ah Advisory Council which play a vital role in all aspects of the organisation in creating the rules and regulation of the organisation to be in line with Shari'ah principles. There is an increase in Shari'ah awareness among staff and Consultants. There were great efforts in transforming the staff culture in line with the new 'Core Values' of a SCH. A biah soleah (Islamic environment) is created in morning supplication, ìbadah guidance to patients and staff, tanīk to babies, and also Islamic reading materials.

In term of human development for staff, the implementation of Usrah and Tazkīrah is mandatory requirement and is part of staff appraisal. Training programs were developed in house on Islamic knowledge and Core Values. We also instilled Islamic awareness by coordinating programs based on Islamic calender and occasion.

In term of facilities to patients, there are Islamic reading materials, brochures on specific issues eg Figh Nisa' fasting and methods of prayer during illness. We also provide guidance and tools for muşolla, tayammum kit, tahnik set and women prayer cloth (telekung). Our Shari'ah compliance officer will carry out Islamic counselling based on the Spiritual Patient Care Assessment. There are also program for patients like Islamic antenatal class, program for kids born at An Nur.

For the staff, they are provided with Islamic uniforms for operation and frontliners. The staff can access to mini library with Islamic books for reference. They have to attend usrah and Tazkīrah weekly during office hours. There are family programs during Islamic occasions eg Iftar Ramaロān, Eid and other Islamic celebrations.

To the shareholders, any handling of share, loans and other financial transactions are carried out in accordance with Shari'ah principles.

\section{CONCLUSION}

The major significant contribution of this study would be to the Shari'ah Compliant Hospital in particular and to the Healthcare industry in general. The demand for a particular treatment in Islamic manner is highly recommended especially to those who are very particular in their Islamic practices and belief.

$\mathrm{SCH}$ covers not only for the physical needs of patients, it also caters and provides for the religious and spiritual needs of patients. It is known fact that that the role of spirituality and religiosity has now being more acceptance not only in Oriental but also in the Western world. ${ }^{11}$

Introduction of $\mathrm{SCH}$ will create a new market demand for:

1. Muslims and even Non-Muslims who believe in segregation of gender especially in medical treatment,

2. Those who demand Islamic environment in term of procedures and practices which will observe certain ruling when carrying out the procedures. Always be reminded with the Qada' and Qadr of Allah when receiving treatment.

3. A model that a Shari'ah compliant organisation is able to portray the relevance of Maqāșid Shari'ah in totality.

4. The position of Wakaf as a fund to assist those patients who are in dire need of financial assistance.

5. Greater understanding of the integration of physical and spiritual needs of the patient. 


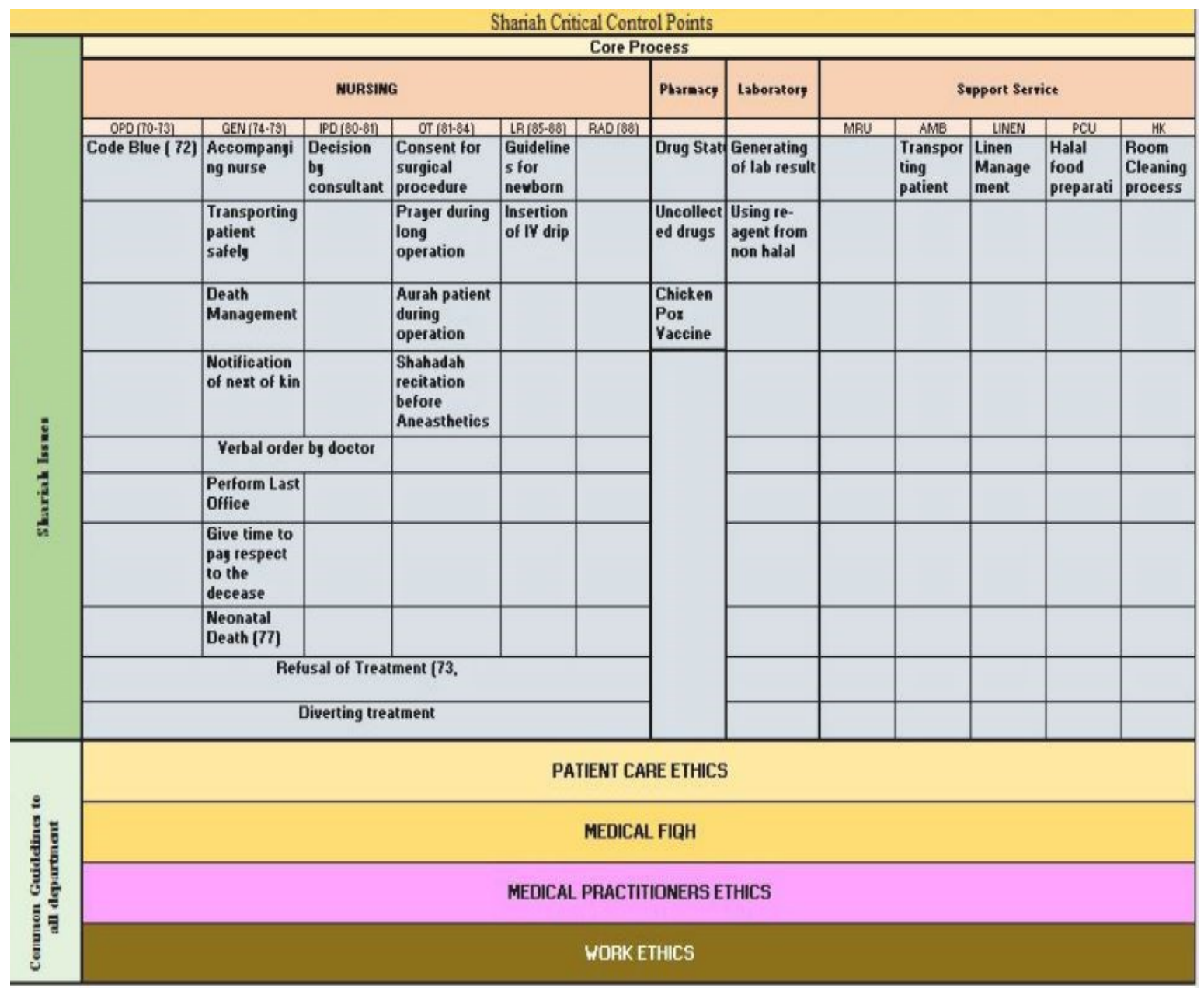

Figure 3. Shari'ah Critical Control Points on Core Processes (courtesy of An Nur Specialist Hospital)

\begin{tabular}{|c|c|c|c|c|c|c|c|}
\hline \multicolumn{8}{|c|}{ Shariah Critical Control Points } \\
\hline \multirow{15}{*}{ 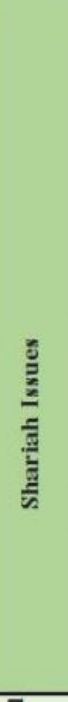 } & \multicolumn{7}{|c|}{ Support Serrice } \\
\hline & Customer Care & Procurement & \begin{tabular}{|c|} 
Bussiness \\
Development and \\
Quality \\
\end{tabular} & Human Resource & Accounts and Finance & $\begin{array}{l}\text { Information } \\
\text { Technology }\end{array}$ & Facilities \\
\hline & Assessment Letter & Credit term & & Interviev session proced & Received payment & & \\
\hline & $\begin{array}{l}\text { Patient Guidance in } \\
\text { sharing room }\end{array}$ & Supplier Registration & & Slot Induction & Patient unable to pay & & \\
\hline & \multicolumn{2}{|c|}{ Major complaint procedure } & & Selection of training pro & $\begin{array}{l}\text { Issue Charge before } \\
\text { treatment }\end{array}$ & & \\
\hline & \multirow[t]{2}{*}{$\begin{array}{l}\text { Misconduct } \\
\text { Investigation }\end{array}$} & & & Staff Negligence proced & Payment Collection & & \\
\hline & & & & & Deposit & & \\
\hline & & & & & Borrovings & & \\
\hline & & & & & Shared Capital Cost & & \\
\hline & & & & & Finance Cost & & \\
\hline & & & & & Insurance I Takaful & & \\
\hline & & & & & Bank Account & & \\
\hline & & & & & Leasing & & \\
\hline & & & & & Other ineome & & \\
\hline & & & & & \multicolumn{2}{|c|}{ Zakat on Bussiness Activity } & \\
\hline \multirow{4}{*}{ 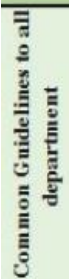 } & \multicolumn{7}{|c|}{ PATIENT CARE ETHICS } \\
\hline & \multicolumn{7}{|c|}{ MEDICAL FIQH } \\
\hline & \multicolumn{7}{|c|}{ MEDICAL PRACTIIIONERS ETHICS } \\
\hline & \multicolumn{7}{|c|}{ WORK FTHICS } \\
\hline
\end{tabular}

Figure 4. Courtesy of An Nur Specialist Hospital : Shari'ah Critical Control Points on Support Services ( courtesy of An Nur Specialist Hospital ) 


\section{REFERENCES}

1. Y Ali, Al Quran: Surah 51: Ayat 56. .

2. I Qayyim, Healing with Medicine of the Prophet, Translated. Maktaba Dar-us-Salam, 2003.

3. J Auda, Maqasid Al Shari'ah: A Beginner's Guide. The International Institute of Islamic Thought, 2008.

4. H A-S Fouad, "Islamic financial product innovation," Int. J. Islam. Middle East. Financ. Manag., vol. 2, pp. 187-200, 2009.

5. DOSM, "Department of Statistics Malaysia Official Portal," 2018. [Online]. Available: https://www.dosm.gov.my/v1/index.php? $\mathrm{r}=$ column/ ctwoByCat\&parent_id=115\&menu_id=LOpheU4 3NWJWRWVSZklWdzQ4TlhUUT09. [Accessed: 16-Mar-2018].

6. Standard Malaysia, "Guide to Malaysian Standard System," 2009. [Online]. Available: http://www.standardsmalaysia.gov.my/ documents $/ 10180 / 86670 /$ Microsoft+Word++MS+System+Handbook.pdf / 3ca67aa7-f4494b1b-b458-fecaa5346c5c.

7. BNM, "Administered Legislation.," Bank Negara Malaysia, 2012. [Online]. Available: http://www.bnm.gov.my/index.php? lang=en\&ch=en_policy.

8. McKinsey, "The World Islamic Banking Competitiveness Report 2007-2008: Capturing the Trillion Dollar Opportunity," 2007.

9. S Shariff and A Rahman, "Shari'ah Compliant Hospital; From Concept to Reality:A Malaysian Experience," Bangladesh Med. Sci., vol. 15, no. 01, pp. 1-4, 2016.

10. MS 1900:2014, "Declaration Of Malaysian Standards," 2014. [Online]. Available: http:// www.standardsmalaysia.gov.my/ documents/10192/316047/Declaration+of+MS+ (Revision) 13012014.pdf/42987365-f498-40cfb795-747201f8d3cd.

11. C M Puchalski, B Blatt, M Kogan, and A Butler, "Spirituality and health: the development of a field.," Acad. Med., vol. 89, no. 1, pp. 10-6, 2014.

12. M K Dr H Masyhudi AM, "KONSEP AKREDITASI INTERNASIONAL RUMAH SAKIT SYARIAH (Berdasar RSI Sultan Semarang)," 2015.

13. N H Kadir, N Ahmad, Z Kefeli, A M Ismail, and Z A Mohamed, "The Implementation of Shariah Compliant Practices Among Selected Medical Tourism Operators In Malaysia," in International Conference Muamalat,Economics \& Islamic Finance, 2014, pp. 124-151.

14. M Mahmud, A M Ismail, N H Kadir, N Ahmad, Z A Mohamed, and Z Kefeli, "Perception Of Medical Tourist Towards Muslim-Friendly Medical Tourism In Malaysia," in International Conference Muamalat, Economics \& alslamic Finance, 2014, pp. 187-197.

15. Z Samori, C For, IHIM Thought, S Alam, and S. Lecturer, "Towards the Formation of Shariah Compliant Hotel in Malaysia: An Exploratory Study on Its Opportunities and Challenges," no. July 2012, pp. 108-124, 2013.

16. N Zafir Md Salleh, A Bakar Abdul Hamid, N Hazarina Hashim, and andSiti Zaleha Omain, "The Practice of Shariah-compliance Hotel in Malaysia," Int. J. Trade, Econ. Financ., vol. 4, no. 1, pp. 26-30, 2014.

17. A Jurattanasan and $\mathrm{K}$ Jaroenwisan, "The Attribution of Shariah Compliant hotel in Muslim Countries Aomarun Jurattanasan Yala Rajabhat University Emailם: Ju_lee_ming@hotmail.com Kaedsiri Jaroenwisan Prince of Songkla University Email: kaedsiri.j@psu.ac.th," Integr. Bus. Econ., vol. 3, pp. 39-44, 2014.

18. J C Henderson, "Sharia-compliant hotels," Tour. Hosp. Res., vol. 10, no. 3, pp. 246-254, Jul. 2010.

19. J Auda, Maqasid Al Shari'ah As Philosophy Of Islamic Law: A Systems Approach. The International Institute of Islamic Thought, 2010.

20. M T Ibn Ashur, Treatise on Maqasid al Shari'ah. London and Washington: International Institue of Islamic Thought, 2006.

21. Mohammad Hashim Kamali, Maqasid Al Shari'ah Made Simple. The International Institute of Islamic Thought, 2008.

22. A S Al-Shaikh-Ali and G Auda, Treatise on Maqasid al-Shari'ah. London And Washington: International Institute of Islamic Thought, 2006.

23. A Al Raysuni, Imam Al Shatibi's Theory of the Higher Objectives and Intents of Islamic Law. London and Washinton:International Institute of Islamic Thought., 2005.

24. A W Dusuki and S Bouheraoua, The framework of Maqasid Al Shari'ah and its Implications for Islamic Finance. Kuala Lumpur:International Institute of Advanced Islamic Studies, 2011.

25. Y Ali, Al Quran: Surah 5 Ayat 32. .

26. A W Dusuki and N I Abdullah, "Maqasid alShariah, Maslaha and Corporate Social Responsibility," Am. J. Islam. Soc. Sci., vol. 2491), pp. 25-45, 2007.

27. S S Abdullah Jalil, Asharaf Mohd Ramli, The four introductory theories of Fiqh Muamalat, 1st ed. Wisdom Publication, Nilai,Negeri Sembilan, 2014.

28. SIRIM, "Corporate Profile SIRIM," 2008.

29. SIRIM QAS Intl., "Corporate Profile SIRIM QAS International," no. 1, 2014.

30. SIRIM QAS Intl, “MS 1900 QMS Islamic Management.pdf." 2014.

31. O H Kasule, "Concept of a hospital in Islam."

32. A H Zulkifly, "IIUM Teaching Hospital: The Way Forward?," Int. Med. J. Malaysia, vol. 13, no. 1, pp. 1-2, 2014.

33. KamaruzzamanWS, "Ideal Islamic concept of IIUM hospital," 2013.

34. P Baxter and S Jac, "Qualitative Case Study Methodology. Study Design and Implementation for Novice Researchers," Qual. Rep., vol. 13, no. 4, pp. 544-559, 2008.

35. R K Yin, Case study research $\square$ : design and methods, vol. 5. 2009. 
2nd World Congress on Integration and Islamicisation 
